\title{
Does National Identity Matter? Political Conditionality and the Crucial Case of Serbia's (Non-)Co-operation with the ICTY*
}

MARIA PAWELEC ${ }^{1}$ and SONJA GRIMM²

${ }^{1}$ University of Bath and Humboldt University of Berlin. ${ }^{2}$ University of Konstanz

\begin{abstract}
Seeking to explain the difficult cases of delayed democratic transition in the Western Balkans, recent literature argues that 'national identity' significantly limits the effectiveness of external actors' political conditionality. This argument is tested in this article by investigating Serbia's co-operation with the International Criminal Tribunal for the former Yugoslavia (ICTY), which was demanded by the United States and the European Union (EU). The findings show that incidents of Serbian co-operation with the ICTY were not preceded by widespread national identity change; rather, co-operation occurred when Serbia was faced with consistent external pressure and the immediate prospect of small-scale rewards. Conditionality thus remained effective. These findings challenge theoretical arguments that issues of national identity may impede external actors' projection of power, independently of domestic actors' cost-benefit calculations. Moreover, they suggest that, in the future, external actors such as the EU may continue to rely upon political conditionality for their democratization agenda, even concerning domestically sensitive issue-areas.
\end{abstract}

\section{Introduction}

Seeking to explain the difficult cases of delayed democratic transition in the Western Balkans, recent literature argues that 'national identity' significantly limits the effectiveness of external actors' political conditionality (Freyburg and Richter, 2010; Peskin, 2008; Subotić, 2010; 2011). Freyburg and Richter (2010, pp. 265-8, italics in the original) hypothesize:

If a state's national identity contradicts the conditions linked to the benefit of an external incentive, even only partially, the state will not or only inconsistently comply with these conditions - independently of any cost-benefit calculation.

Thus, in cases where national identity is incompatible with external actors' demands, domestic actors will not or will only partially comply with externally set political conditions.

In our contribution, we seek to test this appealing theoretical argument by applying it to the crucial case of Serbia's (non-)co-operation with the International Criminal Tribunal for the former Yugoslavia (ICTY): as early as 1997, the European Union (EU)

* We wish to thank Tina Freyburg, Dirk Leuffen, Anselm Lorenzoni, Monika and Graham Pawelec, Solveig Richter, Gerald Schneider and the anonymous reviewers for their helpful suggestions on earlier versions of this article. Special thanks to Claire Bacher for her kind and careful proofreading. 
made Serbia's integration into its post-conflict recovery process conditional upon co-operation with the ICTY (later, Serbia's integration into the EU stabilization and association process (SAP) was also made conditional thereupon). ${ }^{1}$ Serbia's relationship with the ICTY has however - with few exceptions - been characterized by a deliberate refusal to co-operate. This refusal can largely be attributed to the widespread and longstanding perception in Serbia of ICTY indictees as war heroes whose prosecution would call into question Serbia's role in the Balkan wars and thereby challenge Serbian national integrity (see below). It was not until 2011 - 16 years after the end of the war in Bosnia and Herzegovina - that the last fugitives sought by the tribunal were finally arrested (Brammertz, 2011a). How can we explain this development from non-compliance (or at best inconsistent co-operation with the ICTY) to full compliance?

Following the currently well-received argument about the influence of national identity, we would expect to find either a change thereof or at least a reframing of the government's actions as compatible with national identity. However, based on a careful empirical investigation of Serbia's domestic politics and interaction with both the EU and the ICTY between 2000 and 2011, this contribution shows that incidents of co-operation were neither preceded by a widespread identity change nor justified by the government on moral terms. This calls into question the added explanatory value of the 'filter' of national identity for compliance decisions proposed by recent literature as this filter can merely explain Serbia's delay of co-operation but fails to explain Serbia's turn to full compliance with ICTY conditionality.

Rather, we argue that Serbian compliance in fact occurred due to considerable pressure exerted by the United States and later the EU. This partially supports the classical cost-benefit argument: external incentives induce compliance if the benefits exceed the domestic costs of compliance, particularly if an EU membership perspective is offered (Schimmelfennig and Sedelmeier, 2004; Schimmelfennig, 2008, p. 930). However, this cost-benefit argument fails to explain why full co-operation was not achieved earlier given Serbia's longstanding prospect of EU membership. To this effect, we will show that in the case at hand, smaller and more attainable incentives, such as the promise of aid and co-operation agreements, were in fact decisive. It may therefore prove fruitful to modify arguments about the supposed decisiveness of an EU membership perspective so as to take into account the potential influence of such interim incentives.

This contribution challenges two popular hypotheses of the European integration literature: the classical cost-benefit-argument and the hypothesized importance of national identity as a 'filter' thereof. By applying these hypotheses to the crucial case of Serbia's co-operation with the ICTY, it uncovers the limits of their explanatory power and explores the conditions under which seemingly 'tough cases' of EU integration may nevertheless be urged to comply with membership conditions. As opposed to many critics, we argue that the EU will not lose its transformative power in the future if it exerts consistent pressure on (potential) candidate countries and continues to link small steps towards democratization with small rewards in the accession process.

The article will proceed as follows. We begin by summarizing the main findings of the European integration literature and condensing them into two hypotheses adapted to our

${ }^{1}$ While Serbia did not become an independent state until 2006, it dominated the Federal Republic of Yugoslavia until 2002, and was 'de facto independent' within the later State Union with Montenegro (Lamont, 2010, p. 59). 
case. We then provide empirical evidence to test these hypotheses, and go on to discuss their explanatory power and illustrate the weaknesses of both hypotheses.

\section{External Incentives, Social Learning and National Identity}

Numerous contributions to the literature on EU integration and Europeanization suggest that EU political conditionality - rewarding progress towards democratization and economic liberalization by offering a credible EU membership perspective - brings about substantial change if the expected benefits of compliance with EU conditions exceed the expected costs thereof (Grabbe, 2006; Schimmelfennig et al., 2006; Vachudova, 2005). This model thus assumes the 'logic of consequence': rational actors act in accordance with their personal interests and preferences in negotiations and expect gains from co-ordinated action (March and Olsen, 1998, p. 949). According to Schimmelfennig and Sedelmeier (2004, pp. 662, 673), the 'external incentives model' describes the 'dominant logic underpinning EU-conditionality', which 'trumps' all alternative mechanisms if a credible membership perspective exists.

Domestic actors' cost-benefit analyses depend not only on the determinacy of the conditions set by the EU (considered consistently high in the case at hand), but also on the size and speed of rewards. A membership perspective can be regarded as a decisive incentive (Schimmelfennig and Sedelmeier, 2004, pp. 664, 671-3). However, following Anastasakis (2008), we argue that interim incentives such as the provision of financial assistance and co-operation agreements (Grimm and Mathis, 2014) must also be taken into account in order to fully understand the effectiveness of political conditionality - or the lack thereof.

Beyond the size and speed of rewards offered, the credibility of conditionality is also significant (Schimmelfennig and Sedelmeier, 2004, pp. 665ff). Following Anastasakis and Bechev (2003, p. 4), it will be considered high if sanctions and rewards can be imposed and granted by the EU at a low cost to the Union itself, if conditions are consistently linked to rewards over time, if this connection is upheld with regard to other target governments, and if there is no EU-internal discord concerning the application of conditionality.

Finally, domestic adoption costs influences domestic compliance decisions (Schimmelfennig and Sedelmeier, 2004, pp. 663-5). Domestic adoption costs are considered high if compliance with EU conditions could threaten the government's hold on power. They are influenced by public opinion and, at times, by the position of certain parties within governing coalitions when these parties are crucial for a coalition's hold on power. ${ }^{2}$ Additionally, domestic adoption costs increase with a rise in the number of domestic veto players who reject changes to the status quo.

Based on the external incentives model, our first hypothesis for Serbia's co-operation with the ICTY is:

\footnotetext{
${ }^{2}$ If public opinion or party programmes change towards more liberal positions, the costs for incumbent governments to co-operate with the ICTY decrease. However, domestic adoption costs can also decrease due to other factors, including changes in public opinion not related to issues of (national) identity such as increased hopes for economic benefits of co-operation. Therefore, in our analysis, we regard only certain aspects of public opinion as an expression of national identity. Moreover, we regard national identity as more than merely a factor influencing costs, but as a potential filter which, according to the social learning hypothesis, may influence compliance decisions independently of cost-benefit calculations.
} 
H1: Serbia complies with the EU's requirement for co-operation with the ICTY if the expected benefits exceed the domestic costs of compliance.

A second model proposed by the European integration literature is the 'social learning model'. It assumes the 'logic of appropriateness': actors choose the most appropriate course of action, and not the action promising the greatest benefits. The adoption of EU rules by domestic actors depends on the extent to which these rules are perceived as appropriate as well as the extent to which the process of Europeanization is considered legitimate domestically (Checkel, 2001; Schimmelfennig et al., 2006, pp. 27-52).

In order to explain why even pro-democratic governments of EU candidate countries (Albania, Bosnia and Herzegovina, Serbia, Turkey) risked serious economic and political consequences by not complying with EU conditions, Peskin (2008), Subotić (2010; 2011) and Freyburg and Richter (2010) have recently alluded to 'national identity' as the relevant factor significantly limiting the effectiveness of political conditionality.

Several authors (Dragovic-Soso, 2012; Freyburg and Richter, 2010; Schimmelfennig, 2008; Spoerri and Freyberg-Inan, 2008; Subotić, 2010) suggest that the prosecution of war crimes in countries characterized by legacies of ethnic conflict is a condition that explicitly contradicts widespread notions of national identity: indicting generals widely regarded as national heroes challenges many people's conviction that their nations fought a just war and were victims rather than perpetrators. Extraditing them appears tantamount to admitting war guilt (Dragovic-Soso, 2012, p. 173; Schimmelfennig, 2008, p. 928; Subotić, 2013, p. 309). Therefore, ICTY co-operation is perceived as a sensitive issue of national identity in Serbia (Dobbels, 2009, p. 32; Ramet, 2007, pp. 48-51; Schimmelfennig, 2008, p. 928).

If EU conditions are incompatible with notions of national identity, Freyburg and Richter (2010, pp. 266-7, 276) assert that the logic of appropriateness will apply, and material incentives will not affect governments' compliance decisions. However, when conditions trigger national identity conflicts, governments will show inconsistent compliance. If these conflicts finally lead to profound identity change, compliance will be the outcome. $^{3}$

Unfortunately, Freyburg and Richter do not offer a conceptualization of national identity change that may be employed for empirical testing. In this respect, although we recognize that 'national identity' is an essentially contested concept,${ }^{4}$ we propose, for the sake of analysis, to focus on the dominant political narrative in a country and to conceptualize national identity change as a two-dimensional process (see Table 1). First, it incorporates an increased identification with and acceptance of the EU as a 'normative power', a community based on values including democracy and the rule of law (Manners, 2002, p. 239). This acceptance is expressed through trust in the EU, self-identification as European citizens and acceptance of European values such as democracy and the rule of law by both political elites and citizens. ${ }^{5}$ Second, in the case of countries riven by violent ethnic conflict, a change in national identity entails confronting the past - that is, the acknowledgement that compatriots committed war crimes and crimes against humanity

\footnotetext{
${ }^{3}$ Interestingly, Freyburg and Richter's (2010, p. 266) argument is complementary to the external incentives model in that they argue that the logic of consequence applies if conditions do not contradict national identity.

${ }^{4}$ The rephrasing of the scholarly discussion on 'national identity' is beyond the scope of this article. For further discussion, please refer to Anderson (1991); Subotić (2011; 2013); Snyder (2000).

${ }^{5}$ We regard polling data on these questions as a proxy as no other standardized instrument measuring identification with the EU exists to date.
} 
Table 1: Conceptualizing National Identity Change

\begin{tabular}{ccl}
\hline & Dimension & \multicolumn{1}{c}{ Operationalization } \\
\hline $\begin{array}{c}\text { National } \\
\text { identity } \\
\text { change }\end{array}$ & Political elites and & - Increase in trust in EU \\
& citizens accept EU & - Self-identification as European citizens \\
& as normative power & - Acceptance of European values \\
& Political elites and & - Official apology to victims and acknowledgement \\
citizens confront & that war criminals need to be punished \\
war crimes committed & - Public desire to come to terms with the past \\
in the past & - Refusal of political elites and the security apparatus \\
& & to shelter fugitives \\
& - Greater acceptance of ICTY as an institution \\
\hline
\end{tabular}

Source: Authors' own compilation.

while being supported by their state's institutions (Subotić, 2011, p. 312; 2013, p. 309; Spoerri, 2011, p. 1827). Such a change can be officially expressed through an apology from the national executive and legislature to the victims, including the acknowledgement that war criminals need to be punished (Dragovic-Soso, 2012, p. 163). Moreover, such a change may be reflected in public opinion polls revealing a widespread popular desire to come to terms with the past, as well as in a reduction in demonstrations supporting indictees, or in the refusal of political elites and the security apparatus to shelter fugitives. In the case at hand, we would also expect such a change in national identity to be accompanied by a greater acceptance of the ICTY as an international institution established to judge impartially perpetrators of atrocities committed in the Balkan wars. ${ }^{6}$

The social learning model and the reflections on national identity's relevance as a filter for the effectiveness of political conditionality lead to our second hypothesis:

H2: Serbia complies with the EU's requirement for co-operation with the ICTY if it is persuaded of the appropriateness of this requirement.

$H 1$ and $H 2$ will be tested in the remainder of this study through an analysis of Serbia's co-operation with the ICTY. ${ }^{7}$

Serbia presents a crucial case to test empirically the alleged importance of national identity for compliance decisions. As ICTY conditionality was imposed on it for longer than on other former Yugoslav countries (Spoerri, 2011, p. 1828), Serbia provides a fertile testing ground for analyzing compliance over time. Moreover, although Serbia has long aspired to join the EU, the European Commission has (at the time of writing) yet to open accession negotiations with the country - arguably due in large part to its reluctance to co-operate with the ICTY (Subotić, 2011; 2013). According to the literature, Serbia still suffers from strong conflicts of national identity (Peskin, 2008; Ramet, 2007; Spoerri,

\footnotetext{
${ }^{6}$ We follow Spoerri and Freyberg-Inan's (2008, p. 356) that '(a) public opinion data provides vital information on the lack of popularity of the ICTY and (b) helps to establish links between certain political attitudes and associations and their skepticism of the ICTY' - for example, the perception that ICTY co-operation violates dominant notions of Serbian national identity. As no consistent series of opinions polls exists, we triangulated the results of all available polls as a source of complementary evidence.

${ }^{7}$ Both external events and actors may also have influenced Serbia's ICTY co-operation. Our analysis reveals that US-American aid conditionality was initially more influential than EU political conditionality. However, the United States soon lost influence and the EU became the most influential external actor in Serbia after the 2003 Thessaloniki European Council.
} 
2011; Subotić, 2010; 2011, p. 310). It is characterized by a legacy of ethnic and identity conflicts (Clark, 2008, p. 139; Dobbels, 2009, p. 2). Identity-issues, such as notions of a 'Greater Serbia' and the alleged need to protect Serbian nationals in the region 'defending Serbian interests' (Poppov, 2000), caused Slobodan Milosovic's regime to get involved in several wars of succession (Clark, 2008). Even after Milosovic's deposition in 2000, national identity remained salient as political and cultural elites in Serbia promoted the idea that their country was a victim of vast foreign conspiracies aimed at subjugating or destroying it (Ramet, 2007). Among others, Subotić (2013, p. 309) shows that Serbia's national narrative is still dominated by notions 'of a victimized nation, of people struggling, in vain, for national survival, or engaged in an honourable, but futile struggle to defend themselves against one of the myriad and always more powerful enemies'.

Following the social learning argument we would therefore expect Serbia's nonco-operation with the ICTY to be explained by the importance of national identity for domestic reactions to EU pressure. A change in national identity would need to precede compliance with ICTY conditionality. Should this prove not to be the case, then the social learning hypothesis $(H 2)$ offers little explanatory power.

To assess the extent of Serbia's co-operation with the ICTY, we focus on its arrest and transfer of fugitives to The Hague, as this was the EU's highest priority (Dobbels, 2009, p. 17). The group of indicted individuals investigated is limited to ethnic (including Bosnian) Serbs. It can reasonably be assumed that most Serbian indictees were within Serbia's reach at some point in time and that many sought refuge in that country (Del Ponte, 2006a; Orentlicher, 2008, p. 15).

\section{The Empirical Analysis}

Period 1: Non-Co-operation (2000-4)

In 2000, the stage seemed set for Serbia to fulfil the EU's ICTY conditionality and to progress towards membership. On 6 October, Yugoslav President Slobodan Milosevic was ousted from power (Edmunds, 2009, p. 129), and on 23 December, an 18-party 'Democratic Opposition of Serbia' (DOS) coalition won an absolute majority in the parliamentary elections and subsequently formed a government under the pro-European head of the Democratic Party (DS), Zoran Djindjic (ICG, 2004, p. 7).

Notwithstanding these political developments, the period from 2000 to 2004 was characterized by non-compliance according to the tribunal's Chief Prosecutor at the time, Carla Del Ponte. In her addresses to the United Nations Security Council, she reprimanded the federal authorities for 'obstructing the work of the Office of the Prosecutor' (OTP) and Serbia for having become a 'safe haven' for over 15 fugitives. She even claimed that fugitives were warned and went into hiding after the OTP had informed Serbian authorities about their whereabouts (Del Ponte, 2000; 2001; 2002; 2003; 2004).

Several factors account for Serbia's non-co-operation. First, co-operation was not perceived as legitimate and compatible with national identity by the wider population. Under Milosevic, it had regularly been 'served anti-Hague propaganda', and negative attitudes towards the ICTY persisted after his deposition (ICG, 2004, pp. 7ff; Orentlicher,

${ }^{8}$ This point is similarly argued in Peskin (2008); Ramet (2007); Spoerri (2011). 
2008, pp. 13, 28, 66). According to the Helsinki Committee for Human Rights in Serbia, only 36 per cent of the population supported co-operation in 2001 (Del Ponte, 2009, p. 131). In 2002, the South East Europe Public Agenda survey revealed that only 8 per cent of Serb respondents trusted the ICTY (IDEA, 2002). With respect to attitudes towards the past, a survey conducted in May 2001 for independent broadcaster B92 revealed that over 50 per cent of respondents could not name a single crime committed by Serbs during the Yugoslav wars (Clark, 2008, p. 83). In terms of identification with the EU, the World Values Survey showed that only 23.8 per cent of respondents indicated at least a moderate level of trust in the EU in 2001 (WVS, 2001).

Second, the domestic costs of compliance were high as ICTY indictments threatened large segments of the ruling elite, and several powerful veto players existed. While Prime Minister Djindjic backed co-operation with the ICTY, his coalition was deeply divided over the issue (Edmunds, 2009, p. 129). Struggles over the control of the army, the police and the security services - institutions crucial for co-operation - soon led to serious rifts between the DS and the moderately nationalistic Democratic Party of Serbia (DSS) (Clark, 2008, p. 120; Edmunds, 2009, pp. 129, 135). President Vojislav Kostunica, head of the DSS, prevented the DOS coalition from purging the army and security services of Milosevic supporters and attempted to obstruct ICTY co-operation (ICG, 2004, p. 6).

Third, although Serbia had been granted the prospect of EU membership in 2000, it remained only vaguely defined (Council of the EU, 2000). Serbia joined the SAP in late 2000; however, the Western Balkan countries were only granted the status of 'potential candidates', endowing them with no legally enforceable rights (Blockmans, 2007, pp. 281ff).

Non-co-operation was thus the Serbian government's dominant behaviour from 2000 until 2004, with the exceptions of Milosevic's extradition in 2001 - deemed 'groundbreaking' by Del Ponte (2001) - and the extradition of four indictees in early 2002 and five in early 2003. What caused these extraditions? Both the aforementioned polling data and the lack of transfers of other high-ranking indictees suggest that no widespread public consensus in favour of ICTY co-operation had emerged. ${ }^{9}$ It is therefore instructive to analyze these early extraditions more closely with regard to external pressure.

In February 2001, the United States threatened to block Serbia's access to international funds should co-operation with the ICTY not be forthcoming (Lamont, 2010, p. 83). One month later, Serbia extradited the Bosnian Serb Milomir Stakic (Del Ponte, 2009, p. 147) - just over a week before the 31 March certification deadline for the provision of US\$100 million in US-American aid to Serbia, which was conditional upon ICTY co-operation (Woehrel, 2008). One day after the deadline, on 1 April 2001, Milosevic was arrested by Serbian authorities. According to Del Ponte (2009, p. 147), Djindjic deliberately chose this date to avoid the impression that he was acting under US-American pressure. The United States approved the certification on 2 April (Woehrel, 2008, p. 2). Similarly, US-American support for Serbia at an international aid conference in June 2001 was made conditional upon Milosevic's extradition, which occurred one day before the conference. US $\$ 1.3$ billion of aid was subsequently pledged to the Federal Republic of Yugoslavia (Borger and Black, 2001).

${ }^{9}$ However, Djindjic's personal convictions concerning the appropriateness of this step certainly played a role in Milosevic's extradition. 
In 2002, Serbia reverted to non-co-operation, with the exception of one arrest and three 'voluntary' surrenders encouraged by the government (ICTY, 2012). If anything, the beginning of Milosevic's trial in February 2002 strengthened Serbian feelings of victimhood and dislike for the ICTY (Clark, 2008, pp. 100ff). The three surrenders that occurred shortly after the March 2002 deadline for aid passed without certification (Woehrel, 2008, p. 2). On 21 May 2002, the United States certified the provision of aid (Schabas, 2006, p. 387).

In early 2003, five Serbs were extradited by Serbian authorities (ICTY, 2012). This surprising occurrence must be seen within the context of Prime Minister Djindjic's assassination on 12 March 2003 by elements of the security services in an operation tellingly named 'Stop The Hague' (Lamont, 2010, p. 70; Subotić, 2010, p. 601). Shortly thereafter, the government began to crack down on organized crime, amending a flawed law on co-operation with the tribunal and establishing a war crimes chamber within the Belgrade district court (Orentlicher, 2008, pp. 19, 32). Some observers interpret these actions to be the result of a newfound 'social consensus' to confront war crimes (ICG, 2004, p. 9). However, a poll conducted by the Belgrade Centre for Human Rights (BCHR) just two months after Djindjic's assassination suggests that no such consensus existed: while the majority of respondents supported co-operation with the ICTY, only 15 per cent hoped to achieve justice, while 70 per cent supported it for pragmatic reasons such as integration into the international community. Furthermore, 59 per cent opposed co-operation in locating Karadzic and Mladic, and 69 per cent did not trust the tribunal to try accused Serbs impartially (BCHR, 2003). Thus, neither a greater acceptance of the tribunal nor genuine remorse can be discerned. Co-operation in 2003 cannot be traced back to a profound change in dominant perceptions of national identity. Instead, external pressure initiated co-operation once more: Orentlicher (2008, p. 30) and Woehrel (2008, p. 2) link extraditions to the US-American aid certification deadline in June. More importantly however, co-operation occurred around the time of the Thessaloniki European Council at which the credibility of the Western Balkans' accession perspective was decisively raised (Council of the EU, 2003).

\section{Period 2: Inconsistent Co-operation (2005-mid-2008)}

In early 2005, Del Ponte (2005) noted a 'major change' in Serbia's attitude: access to documents and witnesses had improved and numerous indictees had been extradited. As co-operation deteriorated later in the year, this marked the beginning of a period characterized by inconsistent compliance with ICTY conditionality. In 2006, Del Ponte (2006b) stated that 'the Serbian Government could easily arrest Ratko Mladic should the authorities want to do it'. In 2007, she noted 'general progress', including the participation of Serbian authorities in the transfer of two fugitives (Del Ponte, 2007). However, in early 2008 the tribunal's new Chief Prosecutor, Serge Brammertz, once more criticized the lack of arrests (Brammertz, 2008).

During this period, cititzens' willingness to confront the past did not increase. Polling data from the BCHR and the Organization for Security and Co-operation in Europe (OSCE) show that in 2005 and 2006 (as in previous years), more than 60 per cent of respondents did not trust the tribunal to judge Serbs impartially. Less than 20 per cent supported co-operation as a means to achieve justice. Even the public broadcast in June 
2005 of a video showing the execution of several young Muslims by Serb forces near Srebrenica did not decisively increase the population's acknowledgement of war crimes committed by Serbs (Kampschror, 2005). In fact, the abovementioned polls reveal that a steadily decreasing fraction of respondents believed in the importance of facing the past, with the majority wanting to prove Serbia's innocence (BCHR and OSCE, 2006). Political elites condemned the atrocities shown in the video, but political divisions remained too deep for sustained policy change to materialize (Dragovic-Soso, 2012, p. 168).

In early 2005 external pressure caused Serbian compliance. In January, the United States suspended US\$10 million in aid because of non-co-operation and threatened to withdraw its technical advisors from Serbian ministries (Woehrel, 2008, p. 3). In addition, the credibility of both the EU's promised reward of membership and its conditional threats increased: the SAP portfolio was moved to the Directorate General of Enlargement (Dobbels, 2009, p. 14), and Croatia's accession process was delayed in March 2005 due to its failure to hand over General Gotovina (Blockmans, 2007, p. 286). Serbia came under enormous pressure to extradite war criminals as the European Commission was about to decide on the feasibility of opening stabilization and association agreement (SAA) negotiations with the country (Rajkovic, 2008, p. 52).

The sequence of surrenders confirms that EU conditionality was essential. On 25 January 2005, EU Commissioner for Enlargement Olli Rehn arrived in Belgrade. General Lazarevic's 'voluntary' surrender was duly announced three days later (Rajkovic, 2008, p. 53). The European Commission then approved the feasibility report, and US\$10 million in US-American aid was released (Commission, 2005, p. 5; Woehrel, 2008, p. 3).

In the summer of 2005, an impasse over the ratification of an EU constitution called into question the EU's capacity to deliver on its promise of membership (Blockmans, 2007, p. 291). In addition, the EU demonstrated inconsistency in its application of ICTY conditionality: accession negotiations with Croatia were opened although Gotovina remained at large (Blockmans, 2007, p. 286). The EU also opened SAA negotiations with Serbia despite its lack of full co-operation with the tribunal (Blockmans, 2007, pp. 259ff). All of these decisions undermined the credibility of the EU's conditional threats and promises. Serbia subsequently halted all co-operation efforts (Evans and Lyon, 2007). In late 2007, however, two suspects were arrested.

These arrests can neither be explained by a change in the dominant political narrative nor in the attitudes of political elites: a poll conducted in 2007 found that the majority of respondents opposed co-operation with the tribunal (SEIO, 2012). Moreover, President Tadic could not garner parliamentary support to pass a resolution condemning the crimes committed at Srebrenica despite an International Court of Justice ruling in February 2007 that they constituted an act of genocide (Dragovic-Soso, 2012, pp. 168-9; Lamont, 2010, p. 60). Furthermore, popular support for EU integration had dropped: 18 per cent of respondents opposed integration in November 2007 - the highest percentage since 2000. There was also divergence regarding identification with the European community (SEIO, 2012). In the January 2007 parliamentary elections, after a campaign based mainly on disputes about Serbia's past, inter-ethnic questions and European integration, the anti-European SRS won over 29 per cent of the vote and became the strongest party (Bochsler, 2007, p. 161; CEPPS, 2007; Subotić, 2011, p. 322). The February 2008 presidential election was narrowly won by incumbent President Tadic, who escaped a challenge by the Radicals' deputy leader Nikolic (Judah, 2009). 
The question thus remains: How can Serbia's inconsistent co-operation in 2007 and early 2008 be explained? The newly elected coalition government was conflicted concerning identity issues. The DS and the G17+ prioritized ICTY co-operation and European integration, but Kostunica's moderately right-wing nationalist DSS was divided over both and afforded political priority to sovereignty over Kosovo (Woehrel, 2008, p. 6). While the DS was the strongest coalition party, the DSS was prepared to rely on an 'alternative nationalist parliamentary majority' including the SRS to oppose co-operation (ICG, 2008, p. 1). Additionally, neither the police nor the judiciary had been reformed (Clark, 2008, p. 118). The domestic costs of compliance remained high.

With respect to the credibility, size and speed of the EU's conditional threats and promises, the European Commission (2007, p. 5), in an attempt to strengthen proEuropean parties in the process of coalition-building following the 2007 parliamentary elections, signalled its readiness to resume SAA negotiations should 'concrete effective steps towards full cooperation' be taken. This undermined the consistent application of ICTY conditionality as it appeared that further integration was attainable without full co-operation. However, it also provided an incentive for inconsistent and partial compliance. Just two weeks after the new government was formed, Zdravko Tolimir, a top aide to General Mladic, was arrested by Serbian authorities and Vlastimir Djordjevic was arrested in a joint operation with Montenegro in June (Council of Europe, 2007, p. 8). On 13 June 2007, SAA negotiations were resumed, and in September a visa facilitation and re-admission agreement was signed (Commission, 2007, p. 5). The EU thus revised its provision that full co-operation with the tribunal was a prerequisite for continued talks with Serbia (Rajkovic, 2008, p. 62). This serious compromise was caused by internal divisions: several EU Member States had pleaded for loosening ICTY conditionality to appease Serbia on the Kosovo issue, which was gaining pertinence, and to bolster moderate candidate Tadic in the upcoming presidential elections (Del Ponte, 2009, pp. 443ff; Orentlicher, 2008, pp. 34ff). It lowered the credibility of EU conditionality. Consequently, no further fugitives were apprehended in 2007 or early 2008 (Council of Europe, 2007, p. 8). In early 2008 , co-operation was additionally impeded by political uncertainty as Kostunica's government collapsed after Kosovo declared its independence (Brammertz, 2008).

\section{Period 3: Full Co-operation (mid-2008-2011)}

Mid-2008 marked the beginning of a new period characterized by consistently positive reports on Serbia's progress towards fulfilling ICTY conditionality (Brammertz, 2009a; 2009b; 2010). However, a summer 2009 BCHR poll suggests that negative attitudes towards the ICTY persisted: 70 per cent of respondents still did not believe that the tribunal treated Serb defendants impartially. Only 55 per cent now supported co-operation with the tribunal, and 39 per cent opposed it. As in previous surveys, a mere 15 per cent hoped to achieve justice. Furthermore, 64 per cent explicitly opposed extraditing Mladic. If anything, attitudes towards the past became less critical: while more respondents reported having heard about atrocities committed by Serb forces, fewer believed such reports or classified such atrocities as 'war crimes' (BCHR, 2009). Tellingly, although the Serbian parliament condemned the crimes committed at Srebrenica in a declaration on 1 April 2010, it avoided calling the atrocities 'genocide' or declaring anyone responsible 
(Dragovic-Soso, 2012, pp. 316-17). Moreover, later in the year, it issued a 'counterdeclaration' condemning crimes committed against Serbs (Obradovic-Wochnik, 2010, pp. 1-2). In terms of attitudes towards the EU, a poll of political elites conducted in 2008 revealed that only 28.9 per cent of respondents felt a strong personal connection to European values. Nevertheless, an overwhelming majority of 77.5 per cent supported EU membership (Vuletic, 2009, pp. 89ff).

The external incentives model therefore seems to be more apt for explaining Serbia's compliance in late 2008 as the EU sought to prevent the Radicals' anticipated victory in the upcoming parliamentary elections by signing the SAA and an interim agreement on trade and trade-related issues with Serbia on 29 April 2008, despite Mladic's continuing impunity (ICG, 2008, p. 1). However, the SAA's implementation was made conditional upon full ICTY co-operation (Commission, 2008, p. 5). Signing the SAA gave pro-European parties a boost in the 2008 parliamentary elections. The DS won nearly 40 per cent of the popular vote, compared to just over 30 per cent for the SRS and 12 per cent for Kostunica's DSS (CEPPS, 2008). A strongly pro-European governing coalition was formed, excluding the DSS for the first time since 2000 (Judah, 2009). The election results must not be mistaken for a mandate to confront the past as the election campaign had been dominated by the issues of Kosovo and economic development, with the DS 'selling' European integration as a way to improve the economy (ICG, 2008, p. 15). Nevertheless, the domestic costs of compliance were considerably reduced as Kostunica no longer occupied the powerful position of prime minister and SRS negotiating power was significantly lowered (Edmunds, 2009, pp. 128ff; Gordy, 2009, p. 137). Moreover, the army and security services were finally purged of Mladic supporters (Orentlicher, 2008, p. 6).

On 10 June 2008, only days after Brammertz had issued his critical report on Serbia's co-operation, Stojan Zupljanin was arrested and extradited (Gordy, 2009, p. 137). On 21 July 2008, Radovan Karadzic was arrested in Belgrade and transferred to The Hague. As Karadzic had been one of the most prominent fugitives at large (Brammertz, 2009b), this seemed to demonstrate the new government's genuine willingness to comply with ICTY conditionality (Dobbels, 2009, p. 48). Moreover, no serious nationalist backlash ensued after his arrest (Obradovic-Wochnik, 2009, p. 45). However, this does not necessarily signify a more critical attitude towards the past among Serbs; rather, it reflects their widespread desire to "complete the relationship with the ICTY as far as the EU is concerned' (Gordy, 2009, p. 138).

While the SAA implementation remained blocked after Karadzic's arrest due to the Dutch veto on ratification, the European Commission proposed in July 2009 to grant Serbian citizens visa-free travel by January 2010 - a highly sought-after interim reward (Hecimovic, 2009). In so doing, the EU withdrew its claim that Mladic's arrest was a precondition for further integration. Subsequently, Serbia applied for EU membership in December 2009, two days after visa liberalization (Vogel, 2009). Moreover, following Brammertz's positive report to the UN Security Council in December 2009, the EU began to implement the interim agreement, which then entered into force in February 2010 (European Commission, 2010, p. 5). Once more, this suggested that further integration was attainable without full co-operation with the ICTY.

On 26 May 2011, Mladic was finally arrested by Serbian authorities. In his Security Council address, Brammertz (2011b) described this as fulfilling a 'key obligation' to the tribunal and asked that Serbia arrest the last remaining fugitive, Goran Hadzic - a request 
which was promptly fulfilled on 20 July 2011 (McElroy, 2011). In its opinion on Serbia's membership application, the European Commission $(2011$, pp. 8, 12) stated that ICTY co-operation had reached a 'fully satisfactory level' and recommended granting Serbia candidate status, providing it 'reengaged in dialogue with Kosovo'.

Mladic's (and Hadzic's) arrest cannot be explained by a genuine change in dominant perceptions of national identity: a poll by Serbia's National Council for Co-operation with The Hague Tribunal revealed that 40 per cent of respondents still regarded Mladic as a 'national hero' at the time, and that the vast majority (78 per cent) was unwilling to provide any help that could lead to his arrest (Rettman, 2011a). Moreover, Mladic's arrest was never justified by President Tadic on moral grounds; rather, he stressed its importance for Serbia's EU integration (Spoerri, 2011, p. 1841). There is in fact reason to believe that the timing of Mladic's arrest was no coincidence: according to several sources, portions of Brammertz's upcoming address to the Security Council on 6 June 2011 were leaked to the press prior to Mladic's arrest. They revealed that Brammertz was planning to sharply rebuke Serbia for its failure to apprehend Mladic and Hadzic (Rettman, 2011b; McMahon and Western, 2011). Thus, it can be assumed that the Serbian government complied with ICTY conditionality following the logic of consequence: a critical report by Brammertz would have destroyed any chance of Serbia obtaining candidate status in the near future and thus constituted a far greater political liability for President Tadic's upcoming re-election bid than any potential nationalist backlash to the arrest would have done.

\section{Discussing the Hypotheses}

In our empirical analysis, we sought to explain incidents of Serbian co-operation with the ICTY between 2000 and 2011 and to identify why full co-operation was finally achieved. A theory-testing approach was taken, considering both the external incentives hypothesis (H1) and the social learning hypothesis (H2). As shown, recent literature argues that the latter hypothesis $(\mathrm{H} 2)$ applies in potential EU candidate countries riven by ethnic conflict when EU conditions run counter to dominant public or elitist perceptions of national identity. In such cases, one may expect compliance to result only after political elites and a majority of citizens have accepted the EU as a normative power or after they agree to confront war crimes committed in the past - in short: when the dominant identity narrative has changed profoundly. However, our analysis has shown that Serbia co-operated with the ICTY although no such change occurred. In fact, overall identification with the European community remains low. Moreover, ICTY co-operation has never been portrayed by Serbian leaders as a moral or legal obligation, nor has it generally been accepted as such by the public. Serbia thus repeatedly co-operated with the ICTY and finally transferred its remaining fugitives although neither the Serbian elites nor the public were widely persuaded of the appropriateness of this EU condition.

The external incentives hypothesis $(\mathrm{Hl})$ can better explain Serbian co-operation. According to this model, the size and speed of rewards offered by the EU influence domestic actors' compliance decisions. In the first years of Serbia's transition, the timing of extraditions corresponded with US-American aid certification deadlines; however, co-operation slowed each year after these deadlines as the long-term incentive of EU membership remained vague. Later, co-operation was achieved when conditionality was tied to immediate steps in the EU accession process - in particular the Commission's 
feasibility study in 2005 , the potential resumption of SAA negotiations in 2007, the SAA's entry into force in 2008 and the possible rejection of EU candidate status in mid-2011.

The external incentives model also stipulates that the credibility of the EU's conditional threats and promises is crucial. Correspondingly, our analysis has shown that EU conditionality initially proved ineffective because Serbia's membership perspective was vague. However, EU conditionality explains all instances of Serbian compliance after the Thessaloniki European Council in 2003. Moreover, whenever credibility was compromised by doubts over the Union's capacity to deliver the promised rewards or by discrepancies in the application of ICTY conditionality, Serbia complied inconsistently and incompletely. Only the more consistent application of ICTY conditionality from mid-2008 onwards prompted Serbia's full co-operation.

Domestic adoption costs - the third factor influencing compliance with EU conditionality according to the external incentives model - remained consistently high until mid-2008 and obstructed co-operation with the ICTY. At times, domestic actors attempted to strategically lower these costs in the face of high external pressure. In particular, Kostunica framed co-operation in 2005 as consistent with Serbian nationalism (Spoerri, 2011, p. 1844). Moreover, Serbian authorities attempted to obscure their involvement in the two arrests in 2007, which suggests that Kostunica 'wanted to please the West' but did not want to contradict his 'publicly declared policy' of 'voluntary' surrenders (Sadovic, 2007). After the formation of a new government in May 2008, domestic adoption costs fell, enabling Karadzic's arrest and extradition. However, the lack of arrests in 2009 and 2010 shows that a decrease in domestic adoption costs was not a sufficient condition for full co-operation. Mladic's late arrest actually indicates that the new government's approach towards the ICTY and confronting the past had not genuinely changed. Instead, like its predecessors, it chose to co-operate only when extraditions were linked to an immediate step in the accession process.

Serbian compliance in the period under investigation thus occurred solely in reaction to external pressure, initially exerted by the United States and later by the EU. EU conditionality did its job even though conditions were tougher than in the 2004 Eastern enlargement process and touched heavily upon dominant notions of national identity. Therefore, the external incentives hypothesis (HI) explains Serbia's compliance with ICTY conditionality better than the social learning hypothesis (H2). However, it fails to explain why compliance was delayed for so long. To this effect, our analysis has revealed the importance of small-scale rewards: at times, only the prospect of credible and promptly available benefits such as foreign aid and the signing of trade agreements could trigger Serbian compliance.

\section{Conclusions}

From a theoretical perspective, our case study challenges the existing literature on European integration: concerning the external incentives hypothesis, it disputes the widespread conviction that a credible EU membership perspective is the decisive incentive for compliance with EU conditionality. Our case study also questions recent contributions to the literature that suggest "national identity' as a filter for the effectiveness of (EU) political conditionality: while 'national identity' might (rather intuitively) contribute to explaining periods of co-operation delay, it is, in the case at hand, unable to explain the turn to partial 
and later to full compliance with political conditionality. In fact, in Serbia even those actors who never publicly acknowledged that Serbs had committed terrible atrocities during the wars or that there was a moral need to bring perpetrators to justice co-operated with the ICTY. At the same time, no widespread change of national identity occurred among the public. Co-operation with the ICTY was therefore merely enabled by pragmatic considerations: it was regarded as a 'necessary evil' on the path towards EU membership without being accepted as normatively appropriate. Our case study suggests that 'national identity' as an independent factor may in fact contribute little to explaining the effect of political conditionality on countries suffering from unresolved questions of state- and nation-building and of coming to terms with the past.

Our analysis suggests that incentive-based political conditionality remains a potentially powerful instrument of democratization, even towards partner countries that are reluctant to comply. In order to be effective, political conditionality should fulfil three criteria: it should be of small scale; it should be credible; and it should be promptly available. The EU should back officially what it has already begun implicitly: the expansion of the Copenhague criteria towards more fine-grained and direct conditions and rewards. This offers two advantages: it is easier for partner countries to fulfil smaller conditions; and the EU has more options to award progress, but also to punish setbacks in transition. The EU thus need not abandon efforts to exert influence in highly sensitive areas touching on issues of national identity. Instead, in order to trigger decisive progress towards democratization, it need only refine its 'conditionality toolbox' towards offering smaller, more credible and directly attainable rewards.

\section{Correspondence:}

Sonja Grimm

Department of Politics and Public Administration

University of Konstanz

PO Box 86

D-78457 Konstanz

Germany

email: sonja.grimm@uni-konstanz.de

\section{References}

Anastasakis, O. (2008) 'The EU's Political Conditionality in the Western Balkans: Towards a More Pragmatic Approach'. Southeast European and Black Sea Studies, Vol. 8, No. 4, pp. 365-77.

Anastasakis, O. and Bechev, D. (2003) EU Conditionality in South East Europe: Bringing Commitment to the Process (Oxford: Oxford University Press).

Anderson, B. (1991) Imagined Communities: Reflections on the Origin and Spread of Nationalism (London: Verso).

Belgrade Centre for Human Rights (BCHR) (2003) Public Opinion in Serbia: Attitudes towards the ICTY, July 2003 (Belgrade: BCHR).

Belgrade Centre for Human Rights (BCHR) (2009) Attitudes towards the ICTY, 2009 (Belgrade: BCHR).

Belgrade Centre for Human Rights (BCHR) and Organization for Security and Co-operation in Europe (OSCE) (2006) Public Opinion in Serbia: Views on Domestic War Crimes, Judicial Authorities and the Hague Tribunal (Belgrade: BCHR and OSCE). 
Blockmans, S. (2007) Tough Love: The European Union's Relations with the Western Balkans (The Hague: TMC Asser Press).

Bochsler, D. (2007) 'The Parliamentary Election in Serbia, 21 January 2007'. Electoral Studies, No. 27, pp. 160-65.

Borger, J. and Black, I. (2001) 'Huge Aid Promise Prompted Handover'. The Guardian, 29 June.

Brammertz, S. (2008) 'Address to the UN Security Council on 4 June 2008'. The Hague.

Brammertz, S. (2009a) 'Address to the UN Security Council on 4 June 2009'. The Hague.

Brammertz, S. (2009b) 'Address to the UN Security Council on 3 December 2009'. The Hague.

Brammertz, S. (2010) 'Address to the UN Security Council on 18 June 2010'. The Hague.

Brammertz, S. (2011a) 'Statement of the Prosecutor on the Transfer of Ratko Mladić to the ICTY'. The Hague.

Brammertz, S. (2011b) 'Address to the UN Security Council on 6 June 2011'. The Hague.

Checkel, J. (2001) 'Why Comply? Social Learning and European Identity Change'. International Organization, Vol. 55. No. 3, pp. 553-88.

Clark, J. (2008) Serbia in the Shadow of Milošević: The Legacy of Conflict in the Balkans (London: I.B. Tauris).

Commission of the European Communities (2005) 'Communication from the Commission on the preparedness of Serbia and Montenegro to negotiate a stabilisation and association agreement with the European Union'. $\operatorname{COM}(2005) 476$ final.

Commission of the European Communities (2007) 'Serbia 2007 Progress Report'. SEC(2007) 1435.

Commission of the European Communities (2008) 'Serbia 2008 Progress Report'. SEC(2008) 2698 final.

Consortium for Elections and Political Process Strengthening (CEPPS) (2007) IFES Election Guide: Election Profile for Serbia - Parliamentary Elections 2007: Results (Washington, DC: International Foundation for Electoral Systems).

Consortium for Elections and Political Process Strengthening (CEPPS) (2008) IFES Election Guide: Election Profile for Serbia - Parliamentary Elections 2008: Results (Washington, DC: International Foundation for Electoral Systems).

Council of Europe (2007) Serbia: Compliance with Obligations and Commitments and Implementation of the Post-Accession Co-operation Programme, Second Report: Update on developments (November 2006-June 2007) (Strasbourg: Council of Europe).

Council of the European Union (2000) 'Santa Maria da Feira European Council 19 and 20 June 2000: Conclusions of the Presidency'. SN200/00, Feira.

Council of the European Union (2003) 'EU-Western Balkans Thessaloniki Summit: Declaration'. 10229/03 (Presse 163), SN1163/03, Thessaloniki.

Del Ponte, C. (2000) 'Address to the UN Security Council on 24 November 2000'. The Hague.

Del Ponte, C. (2001) 'Address to the UN Security Council on 27 November 2001'. The Hague.

Del Ponte, C. (2002) 'Address to the UN Security Council on 30 October 2002'. The Hague.

Del Ponte, C. (2003) 'Address to the UN Security Council on 10 October 2003'. The Hague.

Del Ponte, C. (2004) 'Address to the UN Security Council on 23 November 2004'. The Hague.

Del Ponte, C. (2005) 'Address to the UN Security Council on 15 December 2005'. The Hague.

Del Ponte, C. (2006a) 'Statement by the Tribunal's Prosecutor on 7 June 2006'. The Hague.

Del Ponte, C. (2006b) 'Address to the UN Security Council on 15 December 2006'. The Hague.

Del Ponte, C. (2007) 'Statement to the UN Security Council on 18 June 2007'. The Hague.

Del Ponte, C. (2009) Madame Prosecutor: Confrontations with Humanity's Worst Criminals and the Culture of Impunity (New York: Other Press).

Dobbels, M. (2009) Serbia and the ICTY: An Analysis of EU Conditionality (Bruges: College of Europe). 
Dragovic-Soso, J. (2012) 'Apologising for Srebrenica: The Declaration of the Serbian Parliament, the European Union and the Politics of Compromise'. East European Politics, Vol. 28, No. 2, pp. 163-79.

Edmunds, T. (2009) 'Illiberal Resilience in Serbia'. Journal of Democracy, Vol. 20, No.1, pp. $128-42$.

European Commission (2010) 'Serbia 2010 Progress Report'. SEC(2010) 1330.

European Commission (2011) 'Commission Opinion on Serbia's application for membership of the European Union: Communication from the Commission to the European Parliament and the Council'. $\operatorname{COM(2011)} 668$ final.

Evans, G. and Lyon, J. (2007) 'No Mladic, No Talks'. New York Times, 21 March.

Freyburg, T. and Richter, S. (2010) 'National Identity Matters: The Limited Impact of EU Political Conditionality in the Western Balkans'. Journal of European Public Policy, Vol. 17, No. 2, pp. 263-81.

Gordy, E. (2009) 'Confronting the Past in Serbia: Obstacles and Opportunities'. In Petritsch, W., Svilanović, G. and Solioz, C. (eds) Serbia Matters: Domestic Reforms and European Integration (Baden-Baden: Nomos).

Grabbe, H. (2006) The EU's Transformative Power: Europeanization through Conditionality in Central and Eastern Europe (New York: Palgrave Macmillan).

Grimm, S. and Mathis, O.L. (2014) 'Stability first, development second, democracy third: The European Union's policy towards post-conflict Western Balkans, 1991-2010'. Europe-Asia Studies, in press.

Hecimovic, A. (2009) 'Serbia's Unearned Reward'. The Guardian, 21 July.

International Criminal Tribunal for the Former Yugoslavia (ICTY) (2012) Case Information Sheets. Available at: «http://www.icty.org/x/cases».

International Crisis Group (ICG) (2004) 'Serbia's U-Turn'. ICG Europe Report 154 (Brussels: ICG).

International Crisis Group (ICG) (2008) 'Will the Real Serbia Please Stand Up?' Europe Briefing 49 (Brussels: ICG).

International Institute for Democracy and Electoral Assistance (IDEA) (2002) South East Europe Public Agenda Survey by the Institute for Democracy and Electoral Assistance (Stockholm: IDEA).

Judah, T. (2009) 'Serbia: Is the Good News Old News?' In Petritsch, W., Svilanović, G. and Solioz, C. (eds) Serbia Matters: Domestic Reforms and European Integration (Baden-Baden: Nomos).

Kampschror, B. (2005) 'Serbs Divided Over Grim Video'. Christian Science Monitor, 15 June.

Lamont, C. (2010) International Criminal Justice and the Politics of Compliance (Farnham: Ashgate).

Manners, I. (2002) 'Normative Power Europe: A Contradiction in Terms?' JCMS, Vol. 40, No. 2, pp. 235-58.

March, J. and Olsen, J. (1998) 'The Institutional Dynamics of International Political Orders'. International Organization, Vol. 52, No. 4, pp. 943-69.

McElroy, D. (2011) 'Arrest of Goran Hadzic Paves Way for Serbia's EU Entry'. The Telegraph, 20 July.

McMahon, P. and Western, J. (2011) 'The Balkans after Mladic: Why the Region Still Needs International Support'. Foreign Affairs online, 23 June.

Obradovic-Wochnik, J. (2009) 'Strategies of Denial: Resistance to ICTY Cooperation in Serbia'. In Batt, J. and Obradovic-Wochnik, J. (eds) War Crimes, Conditionality and EU Integration in the Western Balkans (Paris: European Institute for Security Studies).

Obradovic-Wochnik, J. (2010) Serbia's Srebrenica Declaration: A Small Step, but in the Right Direction (Paris: European Institute for Security Studies). 
Orentlicher, D. (2008) Shrinking the Space for Denial: The Impact of the ICTY in Serbia (New York: Open Society Institute).

Peskin, V. (2008) International Justice in Rwanda and the Balkans: Virtual Trials and the Struggle for State Cooperation (New York: Cambridge University Press).

Poppov, N. (2000) The Road to War in Serbia: Trauma and Carthasis (Budapest: Central European University Press).

Rajkovic, N. (2008) 'The Limits of Consequentialism: ICTY Conditionality and (Non-)Compliance in Post-Milosevic Serbia'. Review of European and Russian Affairs, Vol. 4, No. 1, pp. $27-72$.

Ramet, S. (2007) 'The Denial Syndrome and Its Consequences: Serbian Political Culture since 2000'. Communist and Post-Communist Studies, Vol. 40, No. 1, pp. 41-58.

Rettman, A. (2011a) 'Dutch Take Soft Approach to Serbia War Crimes Case'. EU Observer, 19 May.

Rettman, A. (2011b) 'War Crimes Report Damages Serbia's EU Bid'. EU Observer, 26 May.

Sadovic, M. (2007) Was Tolimir Arrest Staged? (The Hague: Institute for War and Peace Reporting).

Schabas, W.A. (2006) The UN International Criminal Tribunals: the former Yugoslavia, Rwanda and Sierra Leone. Cambridge: Cambridge University Press.

Schimmelfennig, F. (2008) 'EU Political Accession Conditionality after the 2004 Enlargement: Consistency and Effectiveness'. Journal of European Public Policy, Vol. 15, No. 6, pp. 918-37.

Schimmelfennig, F. and Sedelmeier, U. (2004) 'Governance by Conditionality: EU Rule Transfer to the Candidate Countries of Central and Eastern Europe'. Journal of European Public Policy, Vol. 11, No. 4, pp. 661-79.

Schimmelfennig, F., Engert, S. and Knobel, H. (2006) International Socialization in Europe: European Organizations, Political Conditionality and Democratic Change (Basingstoke: Palgrave Macmillan).

Serbian European Integration Office (SEIO) (2012) Public Opinion Poll (Belgrade: SEIO).

Snyder, J. (2000) From Voting to Violence: Democratisation and Nationalist Conflict (New York: Norton).

Spoerri, M. (2011) 'Justice Imposed: How Policies of Conditionality Effect Transitional Justice in Former Yugoslavia'. Europe-Asia Studies, Vol. 63, No. 10, pp. 1827-51.

Spoerri, M. and Freyberg-Inan, A. (2008) 'From Prosecution to Persecution: Perceptions of the International Criminal Tribunal for the Former Yugoslavia (ICTY) in Serbian Domestic Politics'. Journal of International Relations and Development, Vol. 11, No. 4, pp. 350-94.

Subotić, J. (2010) 'Explaining Difficult States: The Problems of Europeanization in Serbia'. East European Politics and Societies, Vol. 24, No. 4, pp. 595-616.

Subotić, J. (2011) 'Europe is a State of Mind: Identity and Europeanization in the Balkans'. International Studies Quarterly, Vol. 55, No. 2, pp. 309-30.

Subotić, J. (2013) 'Stories States Tell: Identity, Narrative and Human Rights in the Balkans'. Slavic Review, Vol. 72, No. 2, pp. 306-26.

Vachudova, M.A. (2005) Europe Undivided: Democracy, Leverage and Integration since 1989 (Oxford: Oxford University Press).

Vogel, T. (2009) 'Serbia Applies for EU Membership'. European Voice, 21 December.

Vuletic, V. (2009) 'Serbia's Political Elite: Attitudes towards European Integration'. In Petritsch, W., Svilanović, G. and Solioz, C. (eds) Serbia Matters: Domestic Reforms and European Integration (Baden-Baden: Nomos).

Woehrel, S. (2008) Conditions on US Aid to Serbia: CRS Report for Congress (Washington, DC: Congressional Research Service).

World Values Survey (WVS) (2001): World Values Survey, 1981-2008: Official Aggregate v.20090901. Available at: «http://www.wvsevsdb.com/». 